DOI: https://doi.org/10.47405/mjssh.v5i3.376

\begin{tabular}{|c|c|}
\hline 84 & Malaysian Journal of Social Sciences and Humanities (MJSSH) \\
\hline $\begin{array}{l}\text { Malaysian Journal of } \\
\text { Social cSiences and }\end{array}$ & Volume 5, Issue 3, March 2020 \\
\hline (MJ - SSH) & e-ISSN : 2504-8562 \\
\hline & $\begin{array}{l}\text { Journal home page: } \\
\text { www.msocialsciences.com }\end{array}$ \\
\hline
\end{tabular}

\title{
The Relationship Between PSiKKIT Factors and Packaging Innovation Behavior: A Survey Among Micro-Food Entrepreneurs
}

\author{
Mahani Amat' ${ }^{1}$, Suraiya Ishak ${ }^{1}$ \\ ${ }^{1}$ Faculty of Social Sciences and Humanities, Universiti Kebangsaan Malaysia (UKM) \\ Correspondence: Mahani Amat (mahanihalimi@gmail.com)
}

\begin{abstract}
The purpose of this study is to determine the relationship between knowledge, attitude, awareness, finance, institutional networking and technology (PSiKKIT) factors and packaging innovation behavior among micro-food entrepreneurs. This study uses a Theory of Planned Behavior is appropriate to be applied in the marketing area and entrepreneurs behavior context. A total of 40 micro entrepreneurs on food under agency guidance in Selangor were selected as a sample through a systematic random sampling technique. The instruments of this study using questionnaires that have been validated by expert to evaluate and have good reliability. The data were analyzed statistically inference using Pearson's correlating test and multiple linear regression techniques. The findings indicate that there is a significant high and positive linear relationship between institutional networking, attitude, awareness and packaging innovation behavior. On the other hand, knowledge, finance and technology indicate non-significant relationship. The findings of this study also reported that the combination of predictor variables PSiKKIT contributed significantly to the behavior of packaging innovation. In fact, the institutional networking as the dominant predictor factor contributes to the innovation behavior of packaging. The implications of this study have been that the factors of PSiKKIT and the behavior of packaging innovations have different influences. The study also suggested that guidance agencies should focus more on institutional networks, raising awareness, financial support and technology support to promote the practice of packaging innovation among micro-food entrepreneurs.
\end{abstract}

Keywords: micro entrepreneurs, packaging, innovation, Theory of Planned Behavior

\section{Introduction}

Packaging as the fifth ' $\mathrm{P}$ ' of marketing mix and it play a vital role on the decision-making of consumers (Khan et al. 2017). Packaging affects every other $P$ in the marketing such as product, price, place and promotion. It is also as a tool for communication to influence consumer buying process. In addition, consumer buying behavior is also likely to be influenced by the innovative packaging. Previous studies have shown that innovative packaging influences consumer behavior in terms of information packaging (Khan et al. 2017), comfort of use and durability (Wyrwa \& Barska 2017), help to prevent the food spoilage and be able to observe the freshness of food inside of packaging (Aday \& Yener 2015). Innovative packaging with the different elements such as color, material, wrapper designs and new packaging techniques also can influence the imagination, emotion, and perception of the consumer (Ahmed et al. 2014; Favier et al. 2019). Indirectly, the innovative and quality of the packaging featured reflects the quality of the product (Anon. 2018a; Handayani et al. 2018). For example, small medium enterprise (SME) changed the packaging with the new graphic design and 
more attractive through the colors and re-positioning the symbols. Although small changes are made, they are able to make a reflection and significant impact on the market through a fresh and modern packaging appearance (Kotler \& Armstrong 2012). Therefore, SME especially micro entrepreneurs need to maintain the consistency of packaging improvements more often.

In Malaysian scenario, packaging has a positive relationship with SME and also influences consumers' decision to buy (Siti Hasnah et al. 2012; Suhaini et al. 2017). Entrepreneurs admit that attractive packaging will be viral among young consumer (Anon. 2018c) and can penetrate the local market and exports (Nabila Yasmin 2018). Unfortunetaley, common problems with micro entrepreneurs' product packaging are unattractive, improper packaging causes products to stink and products easily damaged (Ayupp \& Tudin 2013; Samadi 2014; Suwardi Afandi \& Mohd Arif 2014; Wani et al. 2013). In addition, micro entrepreneurs face challenges in a skills to develop new products, generating new ideas, entrepreneurial risk management, generating knowledge and networking skills (Hasliza et al. 2015; Usai et al. 2018). Innovative behaviors among micro entrepreneurs are still low due to financial constraints and organizational learning capabilities (Suraiya et al. 2015). Many of these problems will affected the future marketing and business performances. Studied showed that innovation practices influences the entrepreneurs business performances (Nasir et al. 2015). On that basis, micro entrepreneurs are encouraged to changing behavior to innovate packaging more attractive to compete in a competitive market.

The changing behavior of packaging innovation among micro entrepreneurs is driven by several factors. Past studies showed that micro entrepreneurial innovation behaviors are driven by organizational work behaviors, technical support, knowledge, institutional networking, attitudes, markets, technology, entrepreneurial orientation and external support services (Alhosseini et al. 2015; Handayani et al. 2018; Mohd Nor Hakimin et al. 2018; Noorazah \& Juhana 2013; Nor Asiah et al. 2016; Phuangrod et al. 2017). Due to this, knowledge, attitude, awareness, finance, institutional networking and technology (PSiKKIT) factors is vital to ensure the innovation behavior of packaging among micro-food entrepreneurs (Mahani \& Suraiya 2019). This study is to determine the relationship between knowledge, attitude, awareness, finance, institutional networking and technology (PSiKKIT) factors and packaging innovation behavior and to determine the predictor variables contribution of PSiKKIT to the behavior of packaging innovation among micro-food entrepreneurs. The relationship between PSiKKIT factors and packaging innovation behavior can best be explained by Ajzen's Theory of Planned Behavior (TPB) (Ajzen 1991).

\section{Literature Review}

The TPB is applied quite comprehensively across several context of social sciences that include marketing area. Chaudhary and Bisai (2018) adapted measures used in the TPB to investigate the consumer behavior towards the products. TPB theory mentioned that individual behavior is influenced by attitude, subjective norms and behavioral control. Based on TPB, individual behavior are shapes by attitudes (Indrayana et al. 2016 and Rezai et al. 2016); and subjective norms such as knowledge (Sulistiyani \& Harwiki 2016) and awareness (Pathak 2014). The packaging innovation behavioral is also influenced by behavioral control such as financial, instituitional networking and technology (Alhosseini et al. 2015; Olcay \& Bulu 2015; Phuangrod et al. 2017; Rosmelisa et al. 2018). Therefore, a study that investigates the relationship between PSiKKIT factors and packaging innovation behavior is implicity be underlies by the Planned Behavior Theory as depicted in Figure 1. 


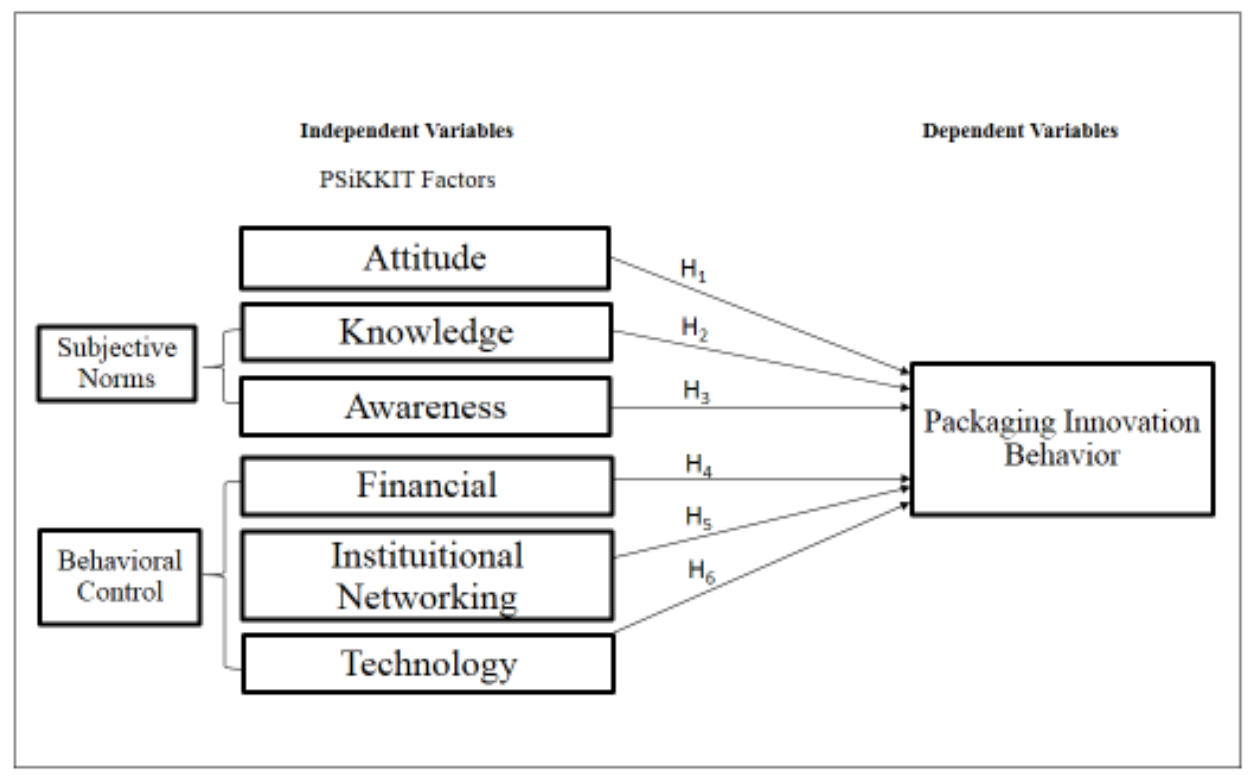

Figure 1: Reasearch framework of packaging innovation behavior

\section{Attitude towards Packaging Innovation Behavior}

Attitude influences behavior and forms individual tendency to act, support or oppose a perception (Hall 2002; Johan et al. 2018; Norazila \& Zamzam 2012; Zainol \& Kamil 2009). Commitment and entrepreneurs' positive attitude will create innovation in a business and influence business performance (Hall 2002; Johan et al. 2018; Lämsä \& Savolainen 2000; Mohd Shaladdin et al. 2011). Johan et al. (2018) stated that entrepreneurs should possess positive attitude, hard work, exert, patient, honest and teamwork. Not only ensuring quality and innovative products packaging, entrepreneurs must also have creative and innovative attitudes that should be instilled in the business. Attitude of an individual will mirror his actions. However, positive attitude will not cause behavior change (Nasrudin et al. 2014).

\section{Knowledge towards Packaging Innovation Behavior}

Knowledge and skills is an important factors and part of innovation success (Omerzel \& Antončič 2008). Salim \& Sulaiman (2011) has shown that organizational learning contributes to the ability to innovate and that there is a positive relationship between packaging innovation and business performance. Knowledge gaps also influences behavior of human decisions or actions and quality effects (Guo \& Meng 2008; McEachern \& Warnaby 2008; Zhao et al. 2017). Increasing in the knowledge, skills and external knowledge sharing activities can transform the business and has a positive effect on packaging innovation performance (Ritala et al. 2015; Suraiya et al. 2018; Wang et al. 2010). On the contrary, lack of knowledge and lack of skill will cause business failure (Fatoki 2014; Tunggak et al. 2011).

\section{Awareness towards Packaging Innovation Behavior}

Awareness towards behavioral, is the tendency to the action oriented behavior. An individual's awareness whether consciously or unconsciously precedes control and changes in individual behavior and decision making (Chartrand 2005). Suraiya and Nur Faridah (2012) found that there is a significant relationship between individual awareness with efficient individual behavior. Usually intention awareness is not enough to change an individual behavior (Nasrudin et al. 2014). 


\section{Financial Support towards Packaging Innovation Behavior}

Financial is a critical factor in influencing the success of a business in implementing packaging innovation (Adigun 2016; Chittithaworn et al. 2011; Diana-Rose et al. 2016; Nor Ghani et al. 2016; Yahaya et al. 2018). Packaging innovation is difficult to be accomplished by the micro food entrepreneurs without sufficient financial support resources (Norkisme et al. 2017; Olcay \& Bulu 2015; Vasilescu 2014). This is to ensure that packaging innovation activity is not restraint because of the lack of financial support resource. However, there are studies stated that innovation is not synonym with financial investment (Felipe \& Márcia 2018). This is because innovation can be done when the business owner is able to organize resources, rearrangement of strategic planning, rationalize the usage of resources and act according to the plan.

\section{Institutional Networkingtowards Packaging Innovation Behavior}

Collaboration micro entrepreneurs with the industry sector had a positive effect on enhancing the packaging innovation (Ueasangkomsate \& Jangkot 2019). Institutional networking can develop the entrepreneurs' attitude, skills and knowledge towards product innovation (Mohd Shaladdin et al. 2011). Other than that, institutional networking acts as the medium of reference and focal point of the entrepreneurs and various parties through Business Matching Program (Abbasi et al. 2017; Olcay \& Bulu 2015; Ombi et al. 2018). Therefore, to strengthen the packaging innovation behavior, the relationship reinforcement between business and government agencies, private agencies and research universities cooperation can increase the packaging innovation knowledge effectively (Pham \& Matsunaga 2019; Powell 2012).

\section{Technology Support towards Packaging Innovation Behavior}

Technology is not only tools or machinery, but also includes technic, skills, method and process that are used to solve real problems (Andersson et al. 2016; Suwardi Afandi et al. 2016). The rapid technology advancement shows improvement in the material used in packaging, packaging method and life span (Sharina et al. 2013). Micro food entrepreneur's technology level is low because of minimum production operation (Zaini et al. 2004). The technology usage is even outdated due to low awareness and the negative mentality of the entrepreneurs towards technology (Azilahwati et al. 2016; Chapman et al. 2000). Therefore, technology support is essential to ensure the production of resistant packaging innovation and suitable with the nature of food (Suraiya et al. 2015).

\section{Research Hypothesis}

Figure 1 also shown the hypothesis for this study will following:

- $\mathrm{H}_{1}$ There is a relationship between Attitude and Packaging Innovation Behavior.

- $\mathrm{H}_{2}$ There is a relationship between Knowledge and Packaging Innovation Behavior.

- $\mathrm{H}_{3}$ There is a relationship between Awareness and Packaging Innovation Behavior.

- $\mathrm{H}_{4}$ Finance is significantly related to Packaging Innovation Behavior.

- $\mathrm{H}_{5}$ Institutional Networking is significantly related to Packaging Innovation Behavior.

- $\mathrm{H}_{6}$ Technology is significantly related to Packaging Innovation Behavior.

\section{Research Methodology}

The study uses a survey design method. The instrument used to collect data was a questionnaire. The questionnaires is divided into nine parts related to the Part A (Demography of Respondents), Part B (Knowledge), Part C (Attitude), Part D (Awareness), Part E (Innovation Packaging Practices), Part F (Finance), Part G (Institutional Networking), Part H (Technology) and Part I (Business Performance). Six poin Likert scale was used to measure PSiKKIT factors and packaging innovation behavior items 
modified from several past research. A reliability test of the constructs was conducted. The Cronbach's alpha of each construct are shown in Table 1.

Table 1: Cronbach's alpha of each construct

\begin{tabular}{lcc}
\hline \multicolumn{1}{c}{ Construct items } & $\begin{array}{c}\text { Cronbach's } \\
\text { alpha value }\end{array}$ & $\begin{array}{c}\text { Strength of } \\
\text { Association }\end{array}$ \\
\hline Attitude & .787 & Good \\
Knowledge & .947 & Excellent \\
Awareness & .866 & Very Good \\
Finance & .914 & Excellent \\
Institutional Networking & .960 & Excellent \\
Technology & .899 & Very Good \\
Innovation Packaging Practices & .983 & Good \\
\hline
\end{tabular}

A total of 50 questionnaires were given out to the micro entrepreneurs on food processing are selected through systematic random sampling of 54 players registered under agency guidance such as Department of Agriculture, FAMA and UPEN in the Selangor area. 45 of the respondents were returned and 40 respondents were eligible to be analyzed as the sample. Response rate of questionnaire is a $90 \%$.

Questionnaire were distributed through the face-to-face meetings and self-administered in online google documents. For the face-to-face meetings, the researcher contacted the micro entrepreneurs to get an appointment and met them personally to seek cooperation for the questionnaires. Meanwhile, self-administered using online google documents, researcher give a link and always keep reminder to the micro entrepreneurs to fill up the online questionnaire. Data was analyzed through quantitative approaches with the use of Statistical Package for Social Sciences (SPSS). Some inferential analysis methods such as correlation Pearson product moment and multiple linear regression (enter) were used in this study.

\section{Results and Discussion}

The findings show that PSiKKIT factors correlate with the packaging innovation behavior. The strongest relationship between instituitional networking and packaging innovation behavior $(r=0.529 * *$, $p=0.00, p<0.01)$. Followed by awareness with packaging innovation behavior $\left(r=0.382^{*}, p=0.15\right.$, $p<0.05)$ and attitude $\left(r=0.361^{*}, p=0.22, p<0.05\right)$ with packaging innovation behavior. This indicates that institutional networking play a vital role and positively influence the behavior of packaging innovation. Awareness and attitude factors also shows the strength of a moderately high relationship towards behavior of packaging innovation. As such, institutional networking, attitudes and awareness can be concluded as the pushing factorsof packaging innovation behavior. The null hypothesis (Ho) of the factors of institutional networking, attitudes and awareness was rejected because there is strong evidence that the three factors are significantly correlated.

Meanwhile, knowledge $(\mathrm{r}=0.152, \mathrm{p}=0.348, \mathrm{p}>0.05)$, financial $(\mathrm{r}=0.150, \mathrm{p}=0.356, \mathrm{p}>0.05)$ and technology $(r=0.220, p=0.172, p>0.05)$ showed that the low relationship between variables was positive correlate towards the packaging innovation behavior. This shows that the knowledge, financial and technology support are weak to influence the packaging innovation behavior. Consequently, knowledge, finance and technology need to be improved for the packaging innovation behavior. The null hypothesis (Ho) showing that knowledge, financial and technology factors fail to reject because there is insufficient evidence and not significantly to reject the null hypothesis. The results of this hypothesis test are summarized in Table 2 and it shows the summary of the correlation Pearson product moment analysis.

Based on the study findings, it is proved that PSiKKIT factors are related to the packaging innovation behavior. This relationship strengthens the TPB theory by Ajzen (1991) that PSiKKIT factors including 
attitude, subjective norms (knowledge, awareness), characters' control (financial, institutional networking, technology) and packaging innovation behavior are interrelated. High correlation value was one of the indicator that institutional networking gave positive effect to the behavior of agency guidance micro food entrepreneurs to do packaging innovation. Institutional networking support does not only develop micro entrepreneurs to increase business performance (Abbasi et al. 2017; Mohd Shaladdin et al. 2011; Olcay \& Bulu 2015; Ombi et al. 2018), but also encourage packaging innovation behavior especially between micro food entrepreneurs. The positive attitudes portrayed by the entrepreneurs also affect the packaging innovation behavior. The positive attitude of the entrepreneurs can be developed by the guidance agencies through continuous guidance and trainings as mentioned by Noorsafiza (2016).

The awareness towards packaging innovation behavior is an action oriented conscious or unconscious intention awareness. Study by Suraiya and Nur Faridah (2012) found that there is a significant relationship between individual awarenss with effective individual behavior. Intention awareness is not enough to change an individual behavior (Nasrudin et al. 2014) without guidance and trainings (Zainol \& Kamil 2009). Awareness can be increased through participation in organized programs to change the entrepreneurs' awareness mentality and produce competent entrepreneurs (Azilahwati et al. 2016; Baird 2017). The strength of knowledge relation in this study context can be increased if knowledge, learning capabilities, module rearrangement and packaging innovation skills are improved. This reason succeeded in expanding the study idea addressed by Fatoki (2014) and Tunggak et al. (2011) that stated entrepreneurs who have high knowledge and skills are able to succeed in business. Past scholars also stated that knowledge can attract innovative behavior among micro entrepreneurs and an organization (Anwar 2018; Guo \& Meng 2008; McEachern \& Warnaby 2008; Suraiya et al. 2018).

The strength of financial relationship towards the micro entrepreneurs packaging innovation behavior can be increased if the micro entrepreneurs have sufficient financial resources. Entrepreneurs should have sufficient financial support resources to realize innovation idea before starting an innovation process (Norkisme et al. 2017). This reason parallels with previous study by Olcay and Bulu (2015) and Vasilescu (2014) who stated that packaging innovation was difficult to accomplish by the small and micro scale entrepreneurs without the support of good financial resource and sufficient funds. This finding is against with Felipe and Márcia (2018) who stated that innovation does not synonym with financial investment. Meanwhile, the strength of technology relationship towards packaging innovation behavior can be increased with the technology support from the guidance agencies. Low technology due to financial constraint, small product productions and overall processing activity do not use machinery (Suraiya et al. 2015; Zaini et al. 2004). However, this finding cannot be seen as a bad scenario. This is because the nature of micro industry usually produces low number of productions causing the technology usage is unsuitable (Suraiya et al. 2015). This is parallel with micro industry nature that produces small scale products and the market is limited to the business surrounding not necessarily needs machine or modern technology. But, micro entrepreneurs can improve the already available tradition technology, use modern technology, retain the old technology, develop new technic or accept technology transfer from the guidance agencies. Past studies also stated technology support from guidance agencies play important roles in packaging technology whether from packaging material usage or technology support (Suraiya et al. 2015; Suwardi Afandi \& Mohd Arif 2014).

Table 2: Relationship correlation analysis between PSiKKIT factors and packaging innovation behavior

\begin{tabular}{lcccc}
\hline & \multicolumn{3}{c}{ Packaging Innovation Behavior } & \\
$\mathbf{N}=\mathbf{4 0}$ & $\boldsymbol{r}$ & $\begin{array}{c}\text { Sig. } \\
(\text { 2-tailed })\end{array}$ & Significance & $\begin{array}{c}\text { Strength of } \\
\text { Relationship }\end{array}$ \\
\hline Attitude & $0.361^{*}$ & .022 & Significant & Highly Moderate \\
Knowledge & 0.152 & .348 & Not significant & Low
\end{tabular}


Malaysian Journal of Social Sciences and Humanities (MJSSH), Volume 5, Issue 3, (page 1 - 12), 2020

DOI: https://doi.org/10.47405/mjssh.v5i3.376

$\begin{array}{lcccc}\text { Awareness } & 0.382^{*} & .015 & \text { Significant } & \text { Highly Moderate } \\ \text { Financial } & 0.150 & .356 & \text { Not significant } & \text { Low } \\ \text { Instituitonal Networking } & 0.529^{* *} & .000 & \text { Significant } & \text { High } \\ \text { Technology } & 0.220 & .172 & \text { Not significant } & \text { Low }\end{array}$

*. Significantly correlate at the level of 0.05 (2-tailed).

**. Significantly correlate at the level of 0.01 (2-tailed).

Furthermore, Table 3 shows the summary of the multiple linear regression analysis that seeks to establish the relationship between PSiKKIT factors and packaging innovation behavior. With an adjusted R-squared of 0.444 percent, it means that PSiKKIT (knowledge, attitude, awareness, finance, institutional networking, and technology) factors $44.4 \%$ of the variations in packaging innovation behavior. The $\mathrm{F}$ value (Table 4 ) of 4.383 indicates that the overall regression model is significant. This signify that there is a significant relationship between the predictor variable of PSiKKIT factors taken together and packaging innovation behavior.

Table 3 also shows that four factors were awareness $(\beta=0.360, t(33)=1.711, p<0.10)$; financial $(\beta=$ $-0.295, \mathrm{t}(33)=-1.743, \mathrm{p}<0.10)$; Institutional networking $(\beta=0.752, \mathrm{t}(33)=4.043, \mathrm{p}<0.01)$ and technology $(\beta=-0.389, \mathrm{t}(33)=-1.972, \mathrm{p}<0.10)$ were significantly predictor factors influencing the behavior of packaging innovation. The other two factors: knowledge $(\beta=0.046, \mathrm{t}(33)=0.329, \mathrm{p}>$ $0.05)$ and attitude, $(\beta=0.086, \mathrm{t}(33)=0.454, \mathrm{p}>0.05)$ were not significantly predictor factors influencing the behavior of packaging innovation in micro entrepreneurs.

Table 3 shows the results of the regression analysis based on the sign of the coefficient and the t-ratio. From the analysis the constant has a t-ratio of 1.271. This indicates that the other factors that affect packaging innovation behavior and have not been included in the model are statistically significant in determining packaging innovation behavior. The constant is also positively related to packaging innovation behavior indicating that the impact of PSiKKIT factors which are not in the model will impact on packaging innovation behavior positively. In addition, institutional networking is a dominant predictor towards packaging innovation behavior.

Table 3: The influence of PSiKKIT variables towards packaging innovation behavior

\begin{tabular}{|c|c|c|c|c|c|c|}
\hline \multirow[t]{2}{*}{ Model } & & \multicolumn{2}{|c|}{$\begin{array}{l}\text { Unstandardized } \\
\text { Coefficients }\end{array}$} & \multicolumn{3}{|c|}{$\begin{array}{l}\text { Standardized } \\
\text { Coefficients }\end{array}$} \\
\hline & & B & Std. Error & Beta & $\mathbf{t}$ & Sig. \\
\hline \multirow[t]{7}{*}{1} & (Constant) & 1.641 & 1.291 & & 1.271 & .213 \\
\hline & Attitude & .099 & .218 & .086 & .454 & .653 \\
\hline & Knowledge & .045 & .137 & .046 & .329 & .744 \\
\hline & Awareness & .489 & .286 & .360 & 1.711 & $.096^{*}$ \\
\hline & Financial & -.385 & .221 & -.295 & -1.743 & $.091 *$ \\
\hline & Institutional Networking & .926 & .229 & .752 & 4.043 & $.000 * *$ \\
\hline & Technology & -.490 & .249 & -.389 & -1.972 & $.057^{*}$ \\
\hline
\end{tabular}

a. Dependent variable: Packaging Innovation Behavior $R=0.666 ; R^{2}=0.444 ;$ Sig. $F=0.002<.01$

*. Significantly correlate at the level of 0.10 (2-tailed).

**. Significantly correlate at the level of 0.01 (2-tailed).

Table 4 Analysis of variance (ANOVA)

\begin{tabular}{llllll}
\hline Model & Total of squared & $\boldsymbol{d} \boldsymbol{f}$ & Min of squared & F & Sig. \\
\hline Regression & 5.207 & 6 & .868 & 4.383 & $.002^{\mathrm{b}}$ \\
Residual & 6.533 & 33 & .198 & & \\
Total & 11.740 & 39 & & & \\
\hline
\end{tabular}




\author{
a. Dependent variable: Packaging Innovation Behavior \\ b. Predictors: (Constant), Technology, Knowledge, Financial, Attitude, Institutional \\ Networking, Awareness
}

This study clearly shows that the institutional networking model $(B=0.752)$ is the dominant predictor factor influencing the behavior of packaging innovation among micro-food entrepreneurs. Statements indicated by standard beta values suggest that an additional unit of predictor of the institutional networking model is associated with an increase of .752 units of behavior of innovation in packaging among micro entrepreneurs. Awareness practitioners have a positive and significant impact predicting for each unit of increasing awareness, the behavior of packaging innovation will increase by .36 standard deviation. Whereas predictors such as finance and technology have negative and significant predictive effects for each financial decline unit, the behavior of packaging innovation will decline by .30 standard deviation. While technology predicts that for each technology decline unit, packaging innovation behavior will decline by .39 standard deviation. Therefore, the coefficient values show that there is a linear relationship to the linear equation model for the packaging innovation behavior with predictor variables as follows:

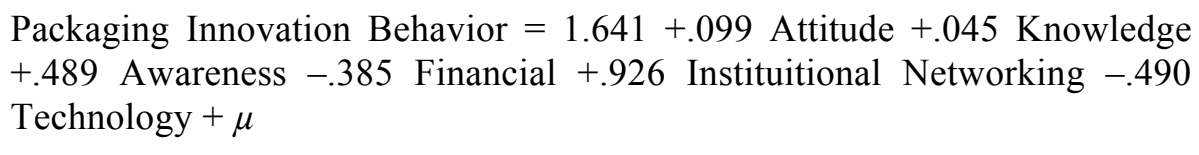

Where, $\mu=$ other determinant factors are not in the equation

This finding indirectly proves that institutional networking support resources as the dominant predictor factor that gives contribution to every unit of packaging innovation behavior among the guidance agencies micro food entrepreneurs. This shows every incremental unit of institutional networking can increase the packaging innovation behavior. This is also proven by Abbasi et al. (2017); Olcay and Bulu (2015); and Ombi et al. (2018) who stated that the guidance agencies roles can help increase business performance and overcome business' internal and external obstacles. Meanwhile awareness factor stated that each incremental unit of the entrepreneurs' awareness level will increase the packaging innovation behavior among the guidance agencies micro food entrepreneurs. Continuous agencies guidance will affect the micro food entrepreneurs for effective packaging innovation behavior. This reason expands the ideas addressed by Zainol and Kamil (2009); and Ardjouman (2014) who stated high awareness will appear when there is an intention in behavior.

Although financial and technology factors are significant, but these factors portray negative influence. Financial and technology constraints will decrease agencies guidance micro food entrepreneurs packaging innovation behavior. Packaging innovation behavior can be increased even with a small changes if it is supported with financial and technology resources. This finding is against with Felipe and Márcia (2018) who stated that innovation is not synonym with financial. Study findings in multiple regression analysis also shows knowledge and attitude are not significant towards packaging innovation behavior among the micro entrepreneurs. This finding is quite surprising as the scientific discussion in past studies overall emphasized that knowledge and attitude influenced packaging innovation (Anwar 2018; Indrayana et al. 2016; Johan et al. 2018; Kollmuss \& Agyeman 2002; Mohd Nor Hakimin et al. 2018; Omerzel \& Antončič 2008; Raffo et al. 2000; Rezai et al. 2016). Therefore, every incremental unit of knowledge will affect packaging innovation behavior if the knowledge is suitable and applied back in the business. Meanwhile, every incremental unit of attitude will affect the packaging innovation behavior if the entrepreneurs' positive attitude is maintained.

\title{
Conclusion
}

Micro entrepreneurs' packaging innovation behavior is related with knowledge, attitude, awareness, financial, institutional networking and technology (PSiKKIT). PSiKKIT predictor factors are able to contribute the increment of packaging innovation behavior among the agencies guidance micro food entrepreneurs. Institutional networking support resources as the dominant predictor factor that gives 
DOI: https://doi.org/10.47405/mjssh.v5i3.376

contribution to packaging innovation behavior among the guidance agencies micro food entrepreneurs. Therefore, institutional networking is seen as the most important to be focused on by the micro entrepreneurs to increase the business and packaging innovation behavior. Meanwhile, financial and technology support resources are important for micro food entrepreneurs to expand and making packaging innovation. The research findings also succeed in proving Planned Behavior Theory (Ajzen 1991) is relevant as the basis of this study to describe PSiKKIT factors towards packaging innovation behavior.

\section{References}

Abbasi, W.A., Wang, Z. \& Abbasi, D.A. (2017). Potential Sources of Financing for Small and Medium Enterprises (SMEs) and Role of Government in Supporting SMEs. Journal of Small Business and Entrepreneurship Development 5(2): 39-47.

Aday, M.S. \& Yener, U. (2015). Assessing consumers??? adoption of active and intelligent packaging. British Food Journal1 17(1): 157-177.

Adigun, A. 2016. To Investigate the Influencing Factors for Sustainable Packaging in a Multinational SME Supply Chain. University of Salford.

Ahmed, R., Parmar, V. \& Ahmed Amin, M. (2014). Impact of Product Packaging on Consumer'S Buying Behavior. European Journal of Scientific Research 122(June 2016): 125-134.

Ajzen, I. (1991). The theory of planned behavior. Organizational Behavior and Human Decision Processes 50(2): 179-211.

Alhosseini, S.S.N., Danai, H. \& Kamrani, M.N. (2015). Impact of Innovation Variables on Quality of Pharmaceutical Products Packaging. Journal of Applied Packaging Research 7(3): 1-22.

Andersson, U., Dasí, À., Mudambi, R. \& Pedersen, T. (2016). Technology, innovation and knowledge: The importance of ideas and international connectivity. Journal of World Business 51: $153-162$.

Anon. (2018a). Pembungkusan produk tarik pelanggan. Sinar Harian (Melaka dan Negeri Sembilan), 48. Seremban.

Anon. (2018b). Jaga kualiti produk. Harian Metro https://www.hmetro.com.my/hati/2018/05/341946/jaga-kualiti-produk.

Anwar, N.A. (2018). Amalan pengurusan kewangan, strategi pemasaran, masalah dan kejayaan usahawan PKS bumiputera. Tesis Sarjana, Fakulti Pendidikan. Universiti Kebangsaan Malaysia.

Ardjouman, D. (2014). Factors Influencing Small and Medium Enterprises (SMEs) in Adoption and Use of Technology in Cote d'Ivoire. International Journal of Business and Management 9(8): 179-190.

Ayupp, K. \& Tudin, R. (2013). Malaysian Food Processing Industry: Strategies for Growth. International Journal of Business and Social Science 4(16): 172-180.

Azilahwati, A., Jessnor Elmy, M.J. \& Sariyah, A. (2016). The Measurement Model of Acceptance and Use of Social Commerce Among Small Medium-Sized Enterprises in Malaysia. Journal of Global Business \& Social Entrepreneurship (GBSE)7(2): 130-140.

Baird, T. (2017). Knowledge of practice: A multi-sited event ethnography of border security fairs in Europe and North America. Security Dialogue 48(3): 187-205.

Chapman, P., James-Moore, M., Szczygiel, M. \& Thompson, D. (2000). Building Internet capabilities in SMEs. Logistics Information Management 13(6): 353-361.

Chartrand, T.L. (2005). The role of conscious awareness in consumer behavior. Journal of Consumer Psychology 15(3): 203-210.

Chaudhary, R. \& Bisai, S. (2018). Factors influencing green purchase behavior of millennials in India. Management of Environmental Quality: An International Journal 29(5): 798-812.

Chittithaworn, C., Islam, A., Keawchana, T. \& Yusuf, D.H.M. (2011). Factors affecting business success of small \& medium enterprises (SMEs) in Thailand. Asian Social Science 7(5): 180190.

Diana-Rose, F., Zariyawati, M.A., Norazlina, K., Annuar, M.A. \& Manisah, O. (2016). Consumers' Purchasing Decision towards Food Products of Small and Medium Enterprises. International Review of Management and Marketing 6(4): 836-842. 
Fatoki, O. (2014). The causes of the failure of new small and medium enterprises in South Africa. Mediterranean Journal of Social Sciences 5(20): 922-927.

Favier, M., Celhay, F. \& Pantin-Sohier, G. (2019). Is less more or a bore? Package design simplicity and brand perception: an application to Champagne. Journal of Retailing and Consumer Services 46: 11-20.

Felipe, F. de L. \& Márcia, R.N.G. (2018). The influence of the specifics of small businesses on innovation. Revista de Gestão 25(3): 242-257.

Guo, L. \& Meng, X. (2008). Consumer knowledge and its consequences: An international comparison. International Journal of Consumer Studies 32(3): 260-268.

Hall, H. (2002). Sharing Capability: The Development of a Framework to Investigate Knowledge Sharing in Distributed Organizations. In Proceedings of the. Third European Conference on Organizational Knowledge, Learning and Capabilities, 5-6 April. Athens.

Handayani, E., Santi Dewi, I.G., Purnomo, W. \& Phitaloka, A.E. (2018). The Legality of food packaging to the production of small and medium enterprises (SME). IOP Conference Series: Earth and Environmental Science $175012191 \mathrm{hlm} .1-8$. IOP Publishing.

Hasliza, A.H., Noor Hazlina, A., Ramayah, T., Haniruzila, H., Taghizadeh, S.K. \& Marini Nurbanum, M. (2015). Towards an Innovation Culture: Enhancing Innovative Performance of Malaysian SMEs. Academic Journal of Interdisciplinary Studies 4(2): 85-94.

Indrayana, B., Seminar, K.B. \& Sartono, B. (2016). Faktor Penentu Minat Penggunaan Instagram Untuk Pembelian Online Menggunakan Technology Acceptance Model (TAM) dan Theory of Planned Behavior (TPB). Jurnal Aplikasi Bisnis dan Manajemen 2(2): 138-147.

Johan, J., Nur Faraeein, Z.A., Jabil, M., Nur Izzah Nabilah, H., Siti Hairah, T. \&Alexander, C.C. (2018). Faktor penentu kejayaan usahawan kuih tradisional di Daerah Papar , Sabah. GEOGRAFIA OnlineTM Malaysian Journal of Society and Space 141(1): 142-157.

Khan, G., Khan, F., Khan, G. \& Khan, F. (2017). The role of packaging and labelling in determining "halalness": an exploratory study of Muslims in two countries. International Journal Islamic Marketing and Branding 2(2): 85-99.

Kollmuss, A. \& Agyeman, J. (2002). Mind the Gap: Why do people act environmentally and what are the barriers to pro-environmental behavior? Environmental Education Research8(3): 239-260.

Kotler, P. \& Armstrong, G. (2012). Principles of Marketing. Edisi ke-14. United States of America: Pearson Prentice Hall.

Lämsä, A.M. \& Savolainen, T. (2000). The nature of managerial commitment to strategic change. Leadership \& Organization Development Journal 21(6): 297-306.

Mahani, A. \& Suraiya, I. (2019). Faktor PSiKKIT: Pendorong inovasi pembungkusan dalam kalangan Industri Kecil dan Sederhana berasaskan perusahaan makanan. Malaysian Journal of Society and Space 15(3): 1-14.

McEachern, M.G. \& Warnaby, G. (2008). Exploring the relationship between consumer knowledge and purchase behaviour of value-based labels. International Journal of Consumer Studies 32(5): 414-426.

Mohd Nor Hakimin, Y., Fakhrul Anwar, Z. \& Hasannuddin, H. (2018). Entrepreneurial Orientation and Usage of External Business Support for SMEs. International Journal of Academic Research in Business and Social Sciences 8(1): 1-11.

Mohd Shaladdin, M., Wan Abdul Aziz, W.M.A. \& Muhammad Abi Sofian, A.H. (2011). Usahawan Kraf di Malaysia: Analisa Laluan Terhadap Perhubungan Inovasi Produk, Komitmen Perniagaan dan Perkembangan Perniagaan. Prosiding Persidangan Kebangsaan Ekonomi Malaysia ke VI (PERKEM VI), Ekonomi Berpendapatan Tinggi: Transformasi ke Arah Peningkatan Inovasi, Produktiviti dan Kualiti Hidup, 5-7 Jun 2011 Vol. 2, hlm. 208-217. Melaka.

Nabila Yasmin, R. (2018). Bungkusan produk elemen penting. Utusan Online, 7 November http://www.utusan.com.my/bisnes/korporat/bungkusan-produk-elemen-penting-1.782266.

Nasir, H., Mansor, M.F. \& Abu, N.H. (2015). The moderating effect of intellectual capital on the relationship of innovation practices in SME's performance. Advanced Science Letters21(5): $1409-1412$.

Nasrudin, N., Rostam, K. \& Che Rose, R.A. (2014). Persepsi penduduk Shah Alam terhadap dasar pengangkutan dan kesediaan mengguna pengangkutan mampan Transportation policies and the 
readiness of local public for sustainable transportation - A perception study of Shah Alam , Malaysia. Malaysian Journal of Society and Space 10(2): 133-142.

Noorazah, M.N. \& Juhana, S. (2013). Model perkongsian pengetahuan dalam organisasi sektor swasta di Malaysia dan hubungannya dengan inovasi dan prestasi organisasi. Jurnal Teknologi (Sciences and Engineering) 64(1): 67-76.

Noorsafiza, M.S. (2016). Pembelajaran di organisasi dan persekitaran kerja terhadap pembentukan tingkah laku kerja inovatif: Kajian perusahaan kecil dan sederhana di Wilayah Ekonomi Pantai Timur, Malaysia. Universiti Kebangsaan Malaysia.

Nor Asiah, O., Hasnan, M.A. \& Muhamad Azrin, N. (2016). The effect of entrepreneurial orientation, innovation capability and knowledge creation on firm performance: A perspective on small scale entrepreneurs. Jurnal Pengurusan 48: 187-200.

Nor Ghani, M.N., Abul Bashar, B., Jamaliah, S. \& Syed, S.A. (2016). Innovation Barriers and Risks for Food Processing SMEs in Malaysia: A Logistic Regression Analysis. Malaysian Journal of Society and Space 12(2): 167-178.

Norazila, M.N. \& Zamzam, M.W. (2012). Faktor Penentu kepada Sinisisme Pekerja terhadap Perubahan Khusus dan Hubungannya dengan Niat untuk Menentang Perubahan dalam Sistem Politeknik di Malaysia. Jurnal Pengurusan 35: 71-86.

Norkisme, Z.A., Nur Riza, M.S. \& Zainol, M. (2017). Faktor utama keupayaan inovasi syarikat milik rakyat Malaysia: Analisis kepentingan-keberkesanan hadapan pesaing perniagaan. Jurnal Pengukuran Kualiti dan Analisis 13(1): 35-54.

Olcay, G.A. \& Bulu, M. (2015). Who should really get government support: an analysis of Turkish SME cases. International Journal of Knowledge-Based Development 6(1):34.

Ombi, N., Ambad, S.N.A. \& Bujang, I. (2018). The Effect of Business Development Services on Small Medium Enterprises (SMEs) Performance. International Journal of Academic Research in Business and Social Sciences 8(3): 117-130.

Omerzel, D.G. \& Antončič, B. (2008). Critical entrepreneur knowledge dimensions for the SME performance. Industrial Management and Data Systems 108(9): 1182-1199.

Pathak, A. (2014). The cognitive power of product packaging. Journal of Business and Management (IOSR-JBM) 16(7): 61-64.

Pham, T.T.T. \& Matsunaga, N. (2019). Product and Process Innovation of Micro, Small and Medium Manufacturing Enterprises in Vietnam. Dlm. Matsunaga, N. (pnyt). Innovation in Developing Countries.Kobe University Monograph Series in Social Science Research hlm. 23-51. Singapore: Springer, Singapore.

Phuangrod, K., Lerkiatbundit, S. \& Aujiraponpan, S. (2017). Factor affecting innovativeness of small and medium enterprises in the five southern border provinces. Kasetsart Journal of Social Sciences 38(3):204-211.

Powell, J. (2012). The university role in the innovative leadership of small to medium sized enterprises. International Journal of Entrepreneurial Behavior \& Research 18(4): 396-416.

Raffo, C., Lovatt, A., Banks, M. \& O'Connor, J. (2000). Teaching and learning entrepreneurship for micro and small businesses in the cultural industries sector. Education + Training 42(6): 356365.

Rezai, G., Sumin, V., Mohamed, Z., Shamsudin, M.N. \& Sharifuddin, J. (2016). Implementing Green Practices as Sustainable Innovation Among Herbal-Based SME Entrepreneurs. Journal of Food Products Marketing 22(1): 1-18.

Ritala, P., Olander, H., Michailova, S. \& Husted, K. (2015). Knowledge sharing, knowledge leaking and relative innovation performance: An empirical study. Technovation 35(November): 22-31.

Rosmelisa, Y., Ng, S.I., Ho, J.A. \& Azmawani, A.R. (2018). The influence of SMEs employees ' intention towards innovative behaviour. Pertanika Journal of Social Sciences \& Humanities 26(3): 1905-1923.

Salim, I.M. \& Sulaiman, M. (2011). Organizational Learning, Innovation and Performance: A Study of Malaysian Small and Medium Sized Enterprises. International Journal of Business and Management 6(12): 118-125.

Samadi, S. (2014). Open Innovation Business Model in the Food Industry: Exploring the Link with Academia and SMEs. Journal of Economics, Business and Management 2(3): 209-213. 
Sharina, S., Zaiha, Z., Mohamad, Y., Nizam, M., Nizat, M., Rozhan, A.D. \& Rohani, C.A. (2013). Khidmat nasihat teknikal MARDI bantu pembangunan PKS. Economic and Technology Management Review 8: 153-163.

Siti Hasnah, H., Wai Leng, L. \& Wong Wai, P. (2012). The influence of food product packaging attributes in purchase decision: A study among consumers in Penang, Malaysia. Journal of Agribusiness Marketing 5: 14-28.

Suhaini, H.M.D., Sahadah, H.A. \& Noor Hasmimi, H.A.G. (2017). The influence of packaging on brand equity in Malaysia small and medium enterprise: a conceptual paper. Journal of Technical and Vocational Education 1(2): 89-98.

Sulistiyani, R. \& Harwiki, W. (2016). How SMEs build innovation capability based on knowledge sharing behavior? Phenomenological approach. Procedia - Social and Behavioral Sciences 219: 741-747.

Suraiya, I., Abd Hair, A., Mohd Yusof, H., Ahmad Raflis, C.O., Sarmila, M.S., Suhana, S., Zaimah, R. \& Azima, A.M. (2015). Penelitian tingkah laku inovasi firma makanan halal kecil di Malaysia: Satu analisis tentatif. GEOGRAFIA OnlineTM Malaysian Journal of Society and Space 11(2): 64-76.

Suraiya, I., Ahmad Raflis, C.O., Fahruddin, M.A.B. \& Lokhman Hakim, O. (2018). Amalan pembelajaran dan kesannya terhadap pembentukan pengetahuan serta kemahiran perniagaan dalam kalangan Generasi Z. Malaysian Journal of Society and Space 14(01): 15-28.

Suraiya, I. \& Nur Faridah, M.Z. (2012). Impact of Consumer Awareness and Knowledge to Consumer Effective Behavior. Asian Social Science 8(13): p108.

Suwardi Afandi, A. \& Mohd Arif, W. (2014). Persepsi pengeluar snek terhadap pembungkusan dan pelabelan. Economic and Technology Management Review 9b: 155-162.

Suwardi Afandi, A., Mohd Yunus, S., Yaseer Suhaimi, M. \& Tapsir, S. (2016). Technology adoption decision among food manufacturers : What are the critical factors? Economic and Technology Management Review 11b: 75-85.

Tunggak, B., Salamon, H. \& Abu, B. (2011). Keperluan Latihan Dan Pendidikan Berterusan Ke Arah Pembangunan Usahawan Muslim Berteraskan Nilai Islam Di Malaysia. Jurnal Teknologi 55(1): 121-144.

Ueasangkomsate, P. \& Jangkot, A. (2019). Enhancing the innovation of small and medium enterprises in food manufacturing through Triple Helix Agents. Kasetsart Journal of Social Sciences 40(2): 389-394.

Usai, A., Scuotto, V., Murray, A., Fiano, F. \& Dezi, L. (2018). Do entrepreneurial knowledge and innovative attitude overcome "imperfections" in the innovation process? Insights from SMEs in the UK and Italy. Journal of Knowledge Management 22(8): 1637-1654.

Vasilescu, L. (2014). Accessing Finance for Innovative Eu Smes - Key Drivers and Challenges. Economic Review: Journal of Economics \& Business 12(2): 35-47.

Wang, Y.L., Wang, Y. De \& Horng, R.Y. (2010). Learning and innovation in small and medium enterprises. Industrial Management and Data Systems 110(2): 175-192.

Wani, A.A., Singh, P. \& Langowski, H.C. (2013). Food Technologies: Packaging. Encyclopedia of Food Safety hlm. 3, 211-218

Wyrwa, J. \& Barska, A. (2017). Packaging as a Source of Information About Food Products. Procedia Engineering 182: 770-779.

Yahaya, J., Ibrahim, S., A.H. (2018). Model Kesediaan Pelaksanaan Teknologi Maklumat untuk Perusahaan Kecil dan Sederhana Ke Arah Era Revolusi Industri 4.0. Ejournals.Ukm.My54.

Zaini, M., Zaimah, D. \& Hasnah, A. (2004). Teknologi dan Kemahiran dalam Industri Skala Kecil. Dlm. Rahmah, I. (pnyt). Industri Kecil Malaysia:Isu Pembiayaan, Teknologi dan Pemasaran hlm. 67-95. Bangi, Selangor: Penerbit UKM.

Zainol, B. \& Kamil, M.I. (2009). Sikap, Norma Subjektif dan Kawalan Gelagat ditanggap terhadap Niat Gelagat Kepatuhan Zakat Pendapatan Gaji. International Journal of Management Studies 16(1): 31-55.

Zhao, A., Szeto, I.M.Y., Wang, Y., Li, C., Pan, M., Li, T., Wang, P. \& Zhang, Y. (2017). Knowledge, attitude, and practice (KAP) of dairy products in chinese urban population and the effects on dairy intake quality. Nutrients $9(668): 1-10$. 